\title{
The Impact of Service-Learning on Students' Key Competences
}

\author{
Alžbeta Brozmanová Gregorová \\ Zuzana Heinzová \\ Katarína Chovancová
}

This article was originally published at:

https://journals.sfu.ca/iarslce/index.php/journal/article/view/246/181

Recommended Citation

Gegorová, A. B., Heinzová, Z., \& Chovancová, K. (2016). The impact of service-learning on students' key competences. International Journal of Research on Service-Learning and Community Engagement, 4(1), 367-376. 


\title{
The Impact of Service-Learning on Students' Key Competences
}

\author{
Alžbeta Brozmanová Gregorová \\ Zuzana Heinzová \\ Katarína Chovancová \\ Matej Bel University, Banská Bystrica, Slovakia
}

\begin{abstract}
Service-learning as a teaching and learning strategy, which combines meaningful service in the community with education, has spread not only in the United States but also in South America, Asia, and Europe in recent years, with the pedagogy being applied at all levels of formal and informal education. In 2005, Matej Bel University, located in Banská Bystrica, Slovakia, developed a servicelearning strategy, and by 2013 its usage had become widespread. This article presents the findings of a study that investigated the development of key competences of two student groups enrolled in courses that incorporated service-learning strategies during academic years 2013-2014 and 2014-2015 at Matej Bel University. The findings of the study suggest that service-learning strategies have positive impacts on the development of students' key competences. The limitations of our study were conducted with a small research (experimental) group of students who passed service-learning course. Based on our research findings we can recommend service-learning as a suitable strategy for students' key competencies development.
\end{abstract}

Keywords: service-learning, key competences, student development

According to the Europe 2020 Strategy, knowledge is the most valuable source of economic growth and an educated populace is Europe's most important form of economic capital (European Commission, 2010). Discussions within the European Union (EU) and beyond, however, have identified the insufficiency of formal systems of education in preparing young people for successful integration into economic systems and societies. Moreover, deeper concerns relating to social cohesion within the context of rapid societal change have arisen. The consequent threat of alienation of individuals from society implies a critical need for the strengthening of democratic citizenship, requiring people to be informed, interested in their society and active within it. As a result, the knowledge, skills, and abilities that individuals need must change in order to address these growing concerns.

Responding to this need, the Council of the European Union and the European Parliament, in late 2006, adopted the European Framework on key competences for lifelong learning. For the first time in Europe, the proposal identified and defined the key competences needed for citizens to achieve personal fulfilment, social inclusion, active citizenship, and employability in a knowledge-based society. Indeed, education and training systems used in the Member States should encourage the development of these competences for all young people. In its report Rethinking Education: Investing in Skills for Better Socio-Economic Outcomes (2012), the European Commission emphasized education as a significant contributor to building active citizenship, enhancing the personal development of individuals, and increasing their employability. However, the achievement of these objectives in formal education through traditional didactic approaches is difficult to imagine. Rather, a constructivist approach to learning, whereby learning is a gradual process characterized by students' active engagement, is required. Service-learning is one such approach.

\section{Key Educational Competences}

The concept of key competences in Europe arose in the workplace in the 1970s, representing a set of specific requirements for job seekers. In the late 1990s, key competences were added to educational programmes to act as a bridge between the requirements imposed by employers on the labour market 
and the competency profile of graduates (Blaško, 2013). For instance, during the Lisbon Process-an action and development plan adopted by the EU in order to address the low productivity and stagnation of economic growth in the EU through the formulation of various EU-wide policy initiatives, including support for innovation and the learning economy-three priorities were set in the selection of key competences:

- the development of the human personality throughout our entire lives, which includes the ability to monitor our own life goals and to educate ourselves over our lifetimes;

- active citizenship and participation in society, which includes the ability to actively involve individuals in societal issues; and,

- individual employability, which includes the ability to obtain adequate and high quality employment in the labour market. (Blaško, 2013, p. 116 )

The Lisbon Process defined competences as a set of knowledge, skills, and attitudes that prepares individuals to address multiple tasks and life situations. Key competences are not directly related to a specific work position but, rather, cover a range of qualifications that go beyond a narrow specialization; thus, they last longer and are applicable to a wider range of situations (Veteška \& Tureckiová, 2008). The development of key competences is one of the starting points of educationsystem reforms at various levels of education. Veteška (2011) suggested that key competences, along with the specific professional competences as well as competences in the field of methods, form the basis not only of the qualified and competent performance of individuals but also of the effective functioning of the organization. Key competences, when adequately utilized, help to secure the employability and integration of individuals within diverse social structures.

In recent years, several models of key competences have been developed in Europe. The Recommendation of the European Parliament and the Council of the European Union (proclaimed December 18, 2006) serves as the unifying framework for key competences for lifelong learning. This European Reference Framework (European Commission, 2007) summarizes eight key competences: communication in the mother tongue; communication in foreign languages; mathematical competence and basic competences in science and technology; digital competence; learning to learn; social and civic competences; sense of initiative and entrepreneurship; and cultural awareness and expression). Distribution of key competences in different areas of personal and social development is illustrative as individual competences overlap and complement each other.

Service-learning, which is a relatively new pedagogical strategy in Slovakia, is virtually unknown in the academic environment or in educational practice. However, two Slovakian universities are developing service-learning pedagogy, and several secondary schools are conducting service-learning pilot projects (in cooperation with one of the universities). Matej Bel University (UMB) in Banská Bystrica is one of the universities focusing specifically on the implementation and development of this strategy. Matej Bel University has been devoted to the development of voluntary student activities since 1998, particularly in cooperation with regional volunteer centres, and has been providing service-learning since 2005. Beginning in 2013, there have been significant quantitative and qualitative advances in the implementation of this strategy in education with the continuous monitoring of service-learning benefits in relation to the development of students' key competences and civic engagement.

The international literature has offered not only definitions of service-learning but also several paradigms and perspectives focusing on this strategy (e.g., Butin, 2010; Jacoby \& Associates, 1996; Moore \& Lan Lin, 2009). The feature common to all of them is the conceptualization of servicelearning as a teaching and learning strategy that integrates meaningful service for the community, education, and reflection. This strategy focuses on both the teaching and learning processes. Accordingly, service-learning at Matej Bel University is defined as an active teaching and learning strategy based on service for others in an effort to develop students' personalities and sense of civic responsibility (Brozmanová Gregorová, Bariaková, Heinzová, Chovancová, Kompán, Kubealaková, Nemcová, Rovňanová, Šolcová \& Tokovská, 2014). Specifically, Matej Bel University applied the following models of service-learning, in line with Jacoby's (1996) recommendations:

- offering courses in which service-learning is an option;

- implementing service-learning as an alternative to classic courses; 
- conducting research in the community; and,

- developing service-learning courses.

The research findings presented in this article relate to a study of students at Matej Bel University who completed a course based on service-learning. At the university, there is an optional two-semester course open to students of all levels and in all study programmes. The course is led by an interdisciplinary team of teachers from different departments, with the aim of developing the students' competences (i.e., knowledge, skills, and attitudes) related to delivering activities for the benefit of others and to project management. The first part of the course is implemented in several teaching blocks. Students acquire theoretical knowledge through creative and active teaching methods. Practical analysis helps them to gain experience in group dynamics and team roles. They learn about careful planning and time management, explore the necessity of aligning objectives with a target group through the choice of an adapted tool to ensure an efficient promotion of their service-learning project within the target group, practise communication in model situations, and acquire skills for drafting budgets (for instance). Reflection precedes self-evaluation and evaluation of each activity.

The second part of the course transfers service activities to the students, who, no later than the end of the summer semester of the academic year, identify their own needs and the needs of the school and community within their group, and then create activities to meet the identified needs. They continue to cooperate with their teachers through mentoring. At least twice a month, the activity is assessed by the student and his or her tutor, from various points of view including planning, implementation, and evaluation. At the end of the summer semester, all students meet and present their implemented activities and their outputs, reflect on their own learning process, and provide an evaluation of the whole course to the other students and to the public. The evaluation session is an integral part of the service-learning course and takes place at the university as a seminar open to all students and teachers of the university.

Since the beginning of this course (in 2013), our intention has been to empirically document not only the various stages of implementation, but also the outputs of the applications. One of the anticipated benefits of a service-learning course is the development of students' key competences. Therefore, we decided to empirically verify this aspect of the implementation of the strategy within teaching practice.

The most significant findings from international research (e.g., Astin \& Sax, 1998; Eyler \& Giles, 1999; Eyler, Giles, \& Braxton, 1997; Eyler, Giles, Stenson, \& Gray, 2001; Fiske, 2001; Melchior, 1999; Morgan \& Streb, 2001; Reed, Jernstedt, Hawley, Reber, \& DuBois, 2005; Williams, King, \& Koob, 2002) - much of which has assessed the impact of service-learning on students - have suggested that service-learning has a positive effect on students in several areas. These areas include the development of the so-called key competences (e.g., communication skills, leadership, cooperation with others, cultural understanding, responsibility, learning, problem-solving skills, development of critical thinking, etc.). Therefore, service-learning naturally fulfils the prerequisites for the development of the key competences of students.

\section{Methods}

Research data pertaining to the assessment of changes in students' subjective perception of their key competence levels were obtained using a competence questionnaire. The basic framework for establishing the list of competences in the research questionnaire was the Recommendation of the European Parliament and the Council of the European Union on key competences for lifelong learning, and an online tool entitled D-zručnosti pre zamestnanie ("V-skills for employability") intended for verification of competences acquired through volunteering and developed within the project VOLWEM, coordinated by Matej Bel University (for more information, see http://www.dzrucnosti.dobrovolnickecentra.sk).

The questionnaire maps the following key competences:

- communication competences (readiness for communication in the mother tongue and in foreign languages). Four abilities are assessed: ability to adequately communicate in the 
mother tongue, ability to communicate in a foreign language, ability to actively listen to others, and ability to participate in discussion.

- digital competences (readiness for using information technologies and information handling). Two abilities are assessed: ability to work with computers and ability to use the Internet.

- mathematical competences and basic competences in science and technology (readiness for creative, critical, and independent problem solving). Three abilities are assessed: ability to perceive, analyse, and independently and creatively solve problems; ability to make decisions and think critically; and ability to manage stress and work under difficult and stressful situations.

- learning to learn competences (readiness for learning). Two abilities are assessed: ability to learn and use new knowledge, and self-motivation to learn.

- social and civic competences (readiness for relationships with other people, self-development, and self-management of personality). Six abilities are assessed: ability to develop and manage personality; self-esteem and self-confidence; ability to participate in teamwork; adaptability and flexibility; responsibility and reliability; and ability to tolerate others.

- sense of initiative and entrepreneurship competences (readiness for employment, for implementation of ideas, a sense for initiative and entrepreneurship, creativity, risk taking, building and developing a professional career). Eight abilities are assessed: entrepreneurial attitude and thinking; ability to manage projects; ability to present and promote; ability to organize one's own time; ability to plan and organize work; ability to adapt to working conditions; ability to lead meetings; and ability to lead other people.

- cultural awareness and expression competences (readiness to engage in civic life and to promote cultural values). Three abilities are assessed: ability to provide assistance in critical situations; protection of cultural traditions; and protection of the environment.

Students conducted self-assessments of 28 abilities within the individual competences, while individual abilities were described in detail by authors of questionnaire in order to avoid erroneous interpretations of the specific abilities.

The impact of service-learning strategy on the subjective perception of students' competence levels was studied for the first time at MBU during academic years 2013-2014 and 2014-2015. In each of the academic years, we used slightly different questionnaires; however, for the purpose of this study, we analysed data from only those items that appeared in the questionnaire during both years.

Students completed the competence questionnaire voluntarily (using pen and paper forms) both before and after taking the service-learning course. All students were informed that survey results would be analysed and presented anonymously, though the institution would be identified.

Respondents assessed the level of their individual skills according to a 5-point Likert scale $(1=$ "very little developed skill, ability" and 5 = "very well developed skill, ability"). The data were analysed using SPSS 19.0. Collected data did not show normal distinctions; therefore, the Wilcoxon test and Mann-Whitney U test were used to detect statistical differences. The reliability of questionnaires was evaluated by using Cronbach's alpha and varied from 0.5 to 0.9 .

Table 1. Cronbach's Alfa of Pre- and Post-Questionnaires

\begin{tabular}{lrr} 
& $\begin{array}{r}\text { Pre- } \\
\text { Questionnaire }\end{array}$ & $\begin{array}{r}\text { Post- } \\
\text { Questionnaire }\end{array}$ \\
\hline Communication competences & 0.50 & 0.52 \\
Digital competences & 0.83 & 0.89 \\
Competences to solve problems & 0.68 & 0.57 \\
Learning to learn & 0.75 & 0.84 \\
Social and personal competences & 0,73 & 0.74
\end{tabular}




$\begin{array}{lcc}\begin{array}{l}\text { Sense of initiative and } \\ \text { entrepreneurship }\end{array} & 0.67 & 0.80 \\ \text { Civic and cultural competences } & 0.75 & 0.77\end{array}$

\section{Results}

Data for the first academic year of the study were collected from 33 students from various study programmes within MBU who had successfully passed the service-learning course in 2013-14 and assessed their competences before and after passing the course. Table 2 presents the pre-post differences in students' completion of the questionnaire during the 2013-2014 academic year.

Table 2. Pre-Post Differences in Students' Perceived Competences (Academic Year 2013-2014) (N = 33)

\begin{tabular}{|c|c|c|c|c|c|c|c|c|c|}
\hline & & & & & & & & & \\
\hline & & Mean & Med & SD & Skew & Kurt & $\mathbf{Z}$ & $\begin{array}{l}\text { p- } \\
\text { value }\end{array}$ & CLES \\
\hline \multirow{2}{*}{$\begin{array}{l}\text { Communication } \\
\text { competences }\end{array}$} & Before & 3.16 & 3 & 1.00 & 0.83 & 0.66 & \multirow{2}{*}{$-3.778 \mathrm{a}$} & \multirow{2}{*}{0.000} & \multirow{2}{*}{-0.66} \\
\hline & After & 3.59 & 4 & 1.05 & 0.12 & -0.07 & & & \\
\hline \multirow{2}{*}{$\begin{array}{l}\text { Digital } \\
\text { competences }\end{array}$} & Before & 3.82 & 4 & 0.74 & -0.93 & 3.17 & \multirow{2}{*}{$-1.024 a$} & \multirow{2}{*}{0.306} & \multirow{2}{*}{-0.18} \\
\hline & After & 4.00 & 4 & 0.82 & -1.21 & 2.50 & & & \\
\hline \multirow{2}{*}{$\begin{array}{l}\text { Competences to } \\
\text { solve problems }\end{array}$} & Before & 3.13 & 3 & 0.72 & -0.79 & 2.46 & \multirow{2}{*}{$-3.633 a$} & \multirow{2}{*}{0.000} & \multirow{2}{*}{-0.63} \\
\hline & After & 3.76 & 4 & 0.81 & -0.56 & 0.83 & & & \\
\hline \multirow{2}{*}{ Learning to learn } & Before & 3.50 & 3 & 0.68 & 0.11 & 0.52 & \multirow{2}{*}{$-2.922 \mathrm{a}$} & \multirow{2}{*}{0.003} & \multirow{2}{*}{-0.52} \\
\hline & After & 3.95 & 4 & 0.67 & -0.93 & 2.30 & & & \\
\hline \multirow{2}{*}{$\begin{array}{l}\text { Social and } \\
\text { personal } \\
\text { competences }\end{array}$} & Before & 3.55 & 4 & 0.90 & -0.50 & 0.37 & \multirow{2}{*}{$-3.716 a$} & \multirow{2}{*}{0.000} & \multirow{2}{*}{-0.65} \\
\hline & After & 4.01 & 4 & 0.75 & -1.69 & 5.93 & & & \\
\hline \multirow{2}{*}{$\begin{array}{l}\text { Sense of initiative } \\
\text { and } \\
\text { entrepreneurship }\end{array}$} & Before & 3.13 & 3 & 0.91 & 1.16 & 2.95 & \multirow{2}{*}{$-3.842 \mathrm{a}$} & \multirow{2}{*}{0.000} & \multirow{2}{*}{-0.67} \\
\hline & After & 3.71 & 4 & 0.86 & -1.09 & 3.24 & & & \\
\hline \multirow{2}{*}{$\begin{array}{l}\text { Civic and cultural } \\
\text { competences }\end{array}$} & Before & 3.40 & 3 & 1.12 & -0.22 & 0.32 & \multirow{2}{*}{$-2.957 \mathrm{a}$} & \multirow{2}{*}{0.003} & \multirow{2}{*}{-0.52} \\
\hline & After & 3.89 & 4 & 0.92 & -0.14 & -0.29 & & & \\
\hline \multirow{2}{*}{ Total } & Before & 3.33 & 3 & 0.36 & 1.25 & 2.40 & \multirow{2}{*}{$-4.085 a$} & \multirow{2}{*}{0.000} & \multirow{2}{*}{-0.71} \\
\hline & After & 3.79 & 4 & 0.52 & -1.43 & 5.64 & & & \\
\hline
\end{tabular}

Note. Med = Median; Skew = Skewness; Kurt = Kurtosis; CLES = Common Language Effect Size.

The data in Table 2 did not show normal distribution; therefore, we used a Wilcoxon test to identify distinctions in subjectively perceived level of competences before and after completion of the service-learning course.

Based on the results, we concluded that there was a statistically significant difference in students' perceived level of competences before and after completing the service-learning course in academic year 2013-2014, with large effect size $(r=-0.52$ to -0.71$)$. Digital competences comprised the only exception, producing no statistically significant distinction. All distinctions between subjectively perceived levels of competences before and after completion of the service-learning course showed higher subjectively perceived level of competences after completing the service-learning course. 
The 2014-2015 data included 30 students from various study programmes within UMB who successfully passed the service-learning course and completed the questionnaire about their competences before and after the course. Table 3 presents the pre-post differences in students' completion of the questionnaire during the 2014-2015 academic year.

Table 3. Pre-Post Differences in Students' Perceived Competences (Academic Year 2014-2015) (N = 30)

\begin{tabular}{|c|c|c|c|c|c|c|c|c|c|}
\hline & & Mean & $\begin{array}{r}\text { Media } \\
\text { n }\end{array}$ & SD & Skew & Kurt. & $\mathbf{Z}$ & $\begin{array}{r}\text { p- } \\
\text { value }\end{array}$ & $\begin{array}{r}\text { CLE } \\
\mathrm{S}\end{array}$ \\
\hline \multirow{2}{*}{$\begin{array}{l}\text { Communication } \\
\text { competences }\end{array}$} & Before & 3.60 & 4 & 0.99 & -0.12 & -0.72 & \multirow{2}{*}{$-2.485 a$} & \multirow{2}{*}{0.013} & \multirow{2}{*}{-0.46} \\
\hline & After & 3.77 & 4 & 1.03 & -0.05 & -0.55 & & & \\
\hline \multirow{2}{*}{$\begin{array}{l}\text { Digital } \\
\text { competences }\end{array}$} & Before & 4.22 & 4 & 0.71 & -0.29 & -0.81 & \multirow{2}{*}{$-0.214 b$} & \multirow{2}{*}{0.83} & \multirow{2}{*}{-0.04} \\
\hline & After & 4.13 & 4 & 0.87 & -1.23 & 2.61 & & & \\
\hline \multirow{2}{*}{$\begin{array}{l}\text { Competences to } \\
\text { solve problems }\end{array}$} & Before & 3.40 & 3 & 0.92 & -0.51 & -0.28 & \multirow{2}{*}{$-2.787 a$} & \multirow{2}{*}{0.005} & \multirow{2}{*}{-0.57} \\
\hline & After & 3.78 & 4 & 0.90 & -0.53 & -1.03 & & & \\
\hline \multirow{2}{*}{$\begin{array}{l}\text { Learning to } \\
\text { learn }\end{array}$} & Before & 3.47 & 3,5 & 0.81 & -0.40 & -0.52 & \multirow{2}{*}{$-1.341 \mathrm{a}$} & \multirow{2}{*}{0.18} & \multirow{2}{*}{$-0,25$} \\
\hline & After & 3.72 & 4 & 0.85 & -1.76 & 4.76 & & & \\
\hline \multirow{2}{*}{$\begin{array}{l}\text { Social and } \\
\text { personal } \\
\text { competences }\end{array}$} & Before & 3.93 & 4 & 0.83 & 0.05 & -0.26 & \multirow{2}{*}{$-1.555 a$} & \multirow{2}{*}{0.12} & \multirow{2}{*}{-0.29} \\
\hline & After & 4.07 & 4 & 0.81 & -0.65 & 1.09 & & & \\
\hline \multirow{2}{*}{$\begin{array}{l}\text { Sense of } \\
\text { initiative and } \\
\text { entrepreneurshi } \\
\text { p }\end{array}$} & Before & 3.30 & 3 & 0.90 & -0.74 & 1.45 & \multirow[b]{2}{*}{$-2.623 a$} & \multirow[b]{2}{*}{0.009} & \multirow[b]{2}{*}{-0.48} \\
\hline & After & 3.60 & 4 & 0.93 & 0.51 & -0.73 & & & \\
\hline \multirow{2}{*}{$\begin{array}{l}\text { Civic and } \\
\text { cultural } \\
\text { competences }\end{array}$} & Before & 3.96 & 4 & 0.83 & -0.09 & 0.11 & \multirow{2}{*}{$-0.920 \mathrm{a}$} & \multirow{2}{*}{0.358} & \multirow{2}{*}{-0.17} \\
\hline & After & 4.00 & 4 & 0.94 & -1.45 & 3.76 & & & \\
\hline \multirow{2}{*}{ Total } & Before & 3.33 & 3 & 0.36 & -0.10 & -0.13 & \multirow{2}{*}{$-2.213 a$} & \multirow{2}{*}{0.027} & \multirow{2}{*}{$-0,41$} \\
\hline & After & 3.83 & 4 & 0.54 & -0.04 & 0.02 & & & \\
\hline
\end{tabular}

Note. Med $=$ Median $;$ Skew $=$ Skewness $;$ Kurt $=$ Kurtosis $;$ CLES $=$ Common Language Effect Size.

Again, the data in Table 3 did not show normal distribution; therefore, we used the Wilcoxon test to identify distinctions in the subjectively perceived level of competences before and after completion of the service-learning course.

Comparison of students' subjectively perceived competences before and after completing the service-learning course in the 2014-2015 academic year showed statistically significant differences in communication competences, mathematical competences, and sense of initiative and entrepreneurship, again showing increased competence after passing the service-learning course, with medium effect size $(\mathrm{r}=-0.46$. to -0.57$)$.

By comparing the results of statistically significant differences in students' perceived competences between the observed academic years, we found that in the 2014-2015 academic year, there was a decrease in the number of key competences in which statistically significant differences were proven after passing the service-learning course. Therefore, we decided to determine if there were any differences in the pretest data between individual years and, subsequently, in the posttest data between the years for each of the students' perceived competences. To investigate the differences between our two independent data sets, we used the Mann-Whitney U test. 
Table 4. Differences in Pre- and Posttest Data between Observed Academic Years and Students' Perceived Level of Competences

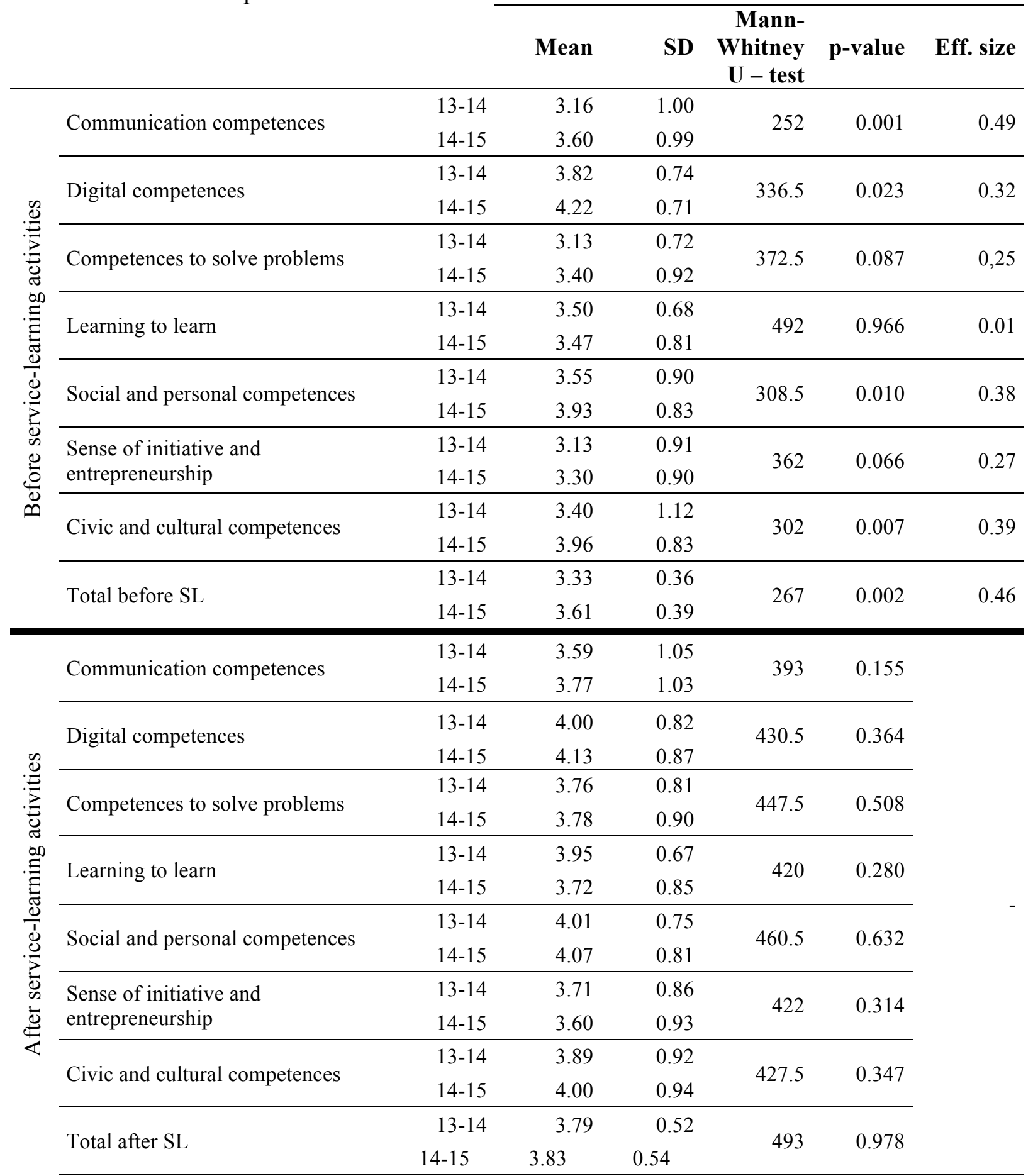

By comparing pretest data concerning students' competences before passing the service-learning course between observed academic years we found statistically significant differences in the subjectively perceived level of students' competences. These differences were observed in communication, digital, social and civic, and cultural awareness and expression, with medium effect size $(r=-0.32$ to -0.49$)$. We noted that when students completed service-learning courses in the two consecutive years, no statistically significant differences were recorded. This suggests that students perceived their level of competences after completion of the service-learning course (posttest) in the same way in both academic years. 


\section{Discussion}

Our results showed that in both academic years, there was a statistically significant pre-post change concerning students' perceived level of key competences. All differences showed higher levels of students' perceived level of key competences after completing the service-learning course. MBU students who successfully passed the course assessed their key competences as being more developed than at the start of the course.

In academic year 2014-2015, statistically significant differences between subjectively perceived levels of competences in three of the seven competences under consideration were recorded, which was lower than in the previous academic year. This phenomenon was most likely related to the fact that students who had already passed the service-learning course in the previous year were also allowed to retake the course in academic year 2014-2015. Because the students filled out the questionnaires anonymously and because we used different coding systems, we do not know the total number of these students (i.e., we only know the number of students who attended the courses). We assumed that these students evaluated their competences as more developed in the entry questionnaire (thanks to completing the service-learning course in the previous academic year), which was then eventually reflected as a lower rate of increase in subjectively perceived competences after the (second) completion of the course.

This phenomenon was also confirmed by our testing of differences in the subjectively perceived level of students' competences between the academic years by entry testing (pretest) and also of differences between academic years by output testing. It was clear that students who evaluated their competences before taking the service-learning course in academic year 2014-2015 evaluated their competences as more developed than the students of the previous year. The fact that students who passed the service-learning course assessed their key competences in the "repeat" questionnaire as more developed is, in our view, a sign of the long-term benefit of the service-learning strategy. The intervening time between evaluations was at least six months.

The results of our study are identical to other, similar studies of the development of skills, competences, and attitudes through service-learning. Sevin, Hale, Brown, and McAuley (2016) confirmed the positive effects of an interprofessional service-learning course on students' selfevaluation of interprofessional competences. Their results demonstrated the effectiveness of servicelearning as a method for preparing students for interprofessional practice, suggesting strongly that interprofessional service-learning courses can be used to develop the knowledge, skills, attitudes, and behaviours required to function in collaborative team-based environments. Likewise, Chavez-Yenter, Badham, Hearld, and Budhwani (2015) studied the connection between the development of competences and attitudes through service-learning and the dynamics of service-learning teams.

Students assessed team dynamics as well as their own competences and attitudes. Those students who experienced poor team dynamics reported significantly lower scores relating to future civic intention, interpersonal and problem-solving skills, and diversity attitudes. It should also be noted that although the differences within the other constructs were not statistically significant, a trend did emerge in which those students who experienced poor team dynamics scored consistently lower than those who experienced excellent team dynamics. Thus, the researchers identified team dynamics as a factor associated with the civic attitudes and skills developed through a service-learning experience. These results are identical to those that emerged in our study, since UMB students also undertake their service-learning activities in teams.

We are aware of the limitations of our study, which was conducted with a small research group of UMB students who took the service-learning course in two academic years and who completed preand post-questionnaires. To confirm the influence of completion of this course on the development of students' perceived competences, data from those who did not take this course in the aforementioned academic years should be included in future research. Moreover, it would be ideal to expand this research into a longitudinal study and to examine more variables that might impact the development of students' key competences through service-learning courses (e.g., the previously mentioned contentment with work in a service-learning team, etc.).

Despite the above-mentioned weak points and in relation to the findings of other researchers doing similar research on key competences, we can conclude that service-learning belongs to the educational strategies that significantly help develop these type of competences. Service-learning creates the space 
for student activities within the community as well as the chance for responsibility assumption in the sense of how their help influences others, how service-learning satisfies the needs of the community, how they help the community and also how they develop themselves.

\section{Author Note}

Alžbeta Brozmanová Gregorová, Department of Social Work, Matej Bel University; Zuzana Heinzová, Department of Psychology, Matej Bel University; Katarína Chovancová, Departmen of Romance Languages, Matej Bel University.

\section{Correspondence}

Correspondence regarding this article should be addressed to Alžbeta Brozmanová Gregorová, Service-Learning Coordinator, Faculty of Education, Matej Bel University, Ružová, 13974 11, Banská Bystrica, Slovakia. Phone: 0421907130817. E-mail: alzbeta.gregorova@umb.sk

\section{References}

Astin, A. W., \& Sax, L. J. (1998). How undergraduates are affected by service participation. Journal of College Student Development, 39(3), 251-263.

Blaško, M. (2013). Kvalita v systéme modernej výučby. Košice, Slovakia: Technická Univerzita.

Brozmanová Gregorová, A., Bariaková, Z., Heinzová, Z., Chovancová, K., Kompán, J., Kubealaková, M., Nemcová, L., Rovňanová, L., Šolcová, J. \& Tokovská, M.. (2014). Service learning: Inovatívna stratégia učenia (sa). Banská Bystrica, Slovakia: Belianum.

Chavez-Yenter, D., Badham, A., Hearld, K. R., \& Budhwani, H. (2015). Service-learning in undergraduate global health education: The effect of team dynamics on civic attitudes and skills. International Journal of Research on Service-Learning and Community Engagement, 3(1), 1-9.

European Commission. (2007). Key competences for lifelong learning. European Reference Framework. Luxembourg: Office for Official Publications of the European Communities.

European Commission. (2010). Europe 2020. A strategy for smart, sustainable and inclusive growth. Brussels: Office for Official Publications of the European Communities.

European Commission. (2012). Rethinking Education: Investing in Skills for Better Socio-economic Outcomes. Stassbourg: Office for Official Publications of the European Communities.

Eyler, J. \& Giles, D. E. (1999). Where's the learning in service-learning? San Francisco: Jossey-Bass.

Eyler, J., \& Giles, D. E., \& Braxton, J. (1997). The impact of service-learning on college students. Michigan Journal of Community Service Learning; 4(1), 5-15.

Eyler, J., Giles, D. E., Stenson, C. M. \& Gray, C. J. (2001). At a glance: What we know about the effects of service-learning on colege students, faculty, institutions and communities, 1993-2000. Nashville, TN: Vanderbilt University.

Fiske, B. E. (2001). Learning in deed: The power of service-learning for American schools. A report from the National Commission on Service Learning. Battle Creek, MI: W. K. Kellogg Foundation.

Jacoby, B., \& Associates. (1996). Service-learning in higher education: Concepts and practices. San Francisco: Jossey Bass.

Melchior, A. Frees, J. LaCava, L. Kingsley, Ch. Nahas, J. (1999). National evaluation of Learn and Serve America school and community based programs. Waltham, MA: Brandeis University.

Moore, M., \& Lin Lan, P. (Ed.) Service-learning in higher education: Paradigms and challenges. Indianapolis: University of Indianapolis Press.

Morgan, W., \& Streb, M. (2001). Building citizenship: How student voice in service-learning develops civic values. Social Science Quarterly, 82(1), 154-169.

Reed, V. A., Jernstedt, C. G., Hawley, J. K., Reber, E. S., \& DuBois, C. A. (2005). Effects of a smallscale, very short-term service-learning experience on college students. Journal of Adolescence, 28(3), 359-368. 
Sevin, A. M., Hale, K. M., Brown N. V., \& McAuley J. W. (2016). Assessing interprofessional education collaborative competencies in service-learning course. American Journal of Pharmaceutical Education, 80(2), 1-8.

Veteška, J. (2011). Teorie a praxe kompetenčního př́stupu ve vzdelávání. Praha, Slovakia: Educa Service.

Veteška, J., \& Tureckiová, M. (2008). Kompetence ve vzdělávání. Praha, Slovakia: Grada.

Williams, N., King, M., \& Koob, J.J. (2002). Social work students go to camp: The effect of service learning on perceived self-efficacy. Journal of Teaching in Social Work, 22(3/4), 55-70. 